\title{
Native Trichoderma for the Management of Wire Stem of mustard (Brassica spp) Caused by Rhizoctonia solani
}

\author{
R.K. Nirupama Devi, Bireswar Sinha* and Ph. Sobita Devi
}

\author{
Department of Plant Pathology, College of agriculture, CAU, Imphal, Manipur, India \\ *Corresponding author
}

\begin{tabular}{|l|}
\hline Ke y w o r d s \\
Mustard, \\
Trichoderma, Bio- \\
priming.
\end{tabular}

A B S T R A C T
In vitro study on the effect of four Trichoderma isolates on the mycelial growth of Rhizoctonia solani showed maximum inhibition of 74.54 per cent and least inhibition of 52.50 per cent. Effects of volatile compound produced by Trichoderma spp. against $R$. solani were ranged from 15.50 to 26.70 per cent. Non-volatile compound produced by Trichoderma spp showed inhibition of 7.45 to 31.11 per cent at $7.5 \% \mathrm{v} / \mathrm{v}$ concentrations and 14.50 to 33.55 per cent at $15 \% \mathrm{v} / \mathrm{v}$. Experiment on competitive parasitic ability of four Trichoderma isolates in the colonization of sclerotia under three different soil conditions viz., unsterilized, sundried and sterilized soil showed highest colonization of isolates CAUNCIPM-116, CAUNCIPM-97A, CAUNCIPM-11 and CAUNCIPM-50 (100 per cent) sterilized soil. Bio priming of mustard seeds by Trichoderma isolates showed highest shoot length of $4.90 \mathrm{~cm}$ by Trichoderma isolate CAUNCIPM-97A and highest root length of $1.47 \mathrm{~cm}$ in isolate CAUNCIPM-11. Highest vigour index was observed in isolate CAUNCIPM-97A treated seed. Fungal microbial population from the rhizosphere of mustard was taken at 15 days and 30 days after sowing and highest number of fungal population was observed in seed + soil treated with isolate CAUNCIPM-97A and CAUNCIPM-116 respectively. In vivo efficacy of four isolates viz., CAUNCIPM-116, CAUNCIPM-97A, CAUNCIPM-11 and CAUNCIPM-50 of Trichoderma against $R$. solani Kuhn. showed significant reduction in disease incidences under pot condition and beside chemical (Blitox) treated pot, combination of seed and soil treatment with Trichoderma isolates showed highest plant growth characters pot such as germination percentage, plant height, plant canopy, fresh weight and dry weight than seed and soil alone.

\section{Introduction}

Mustard (Brassica sp.) is the important Rabi oilseed crops of India. They occupy a prominent place being next to groundnut, both in area and production. It is considered to be a crop of tropical as well as temperate zone and require relatively cool temperature for satisfactory growth and yield. It belongs to genus Brassica of the family Cruciferous with large number of species and sub species cultivated in India. Brassica juncea L. was originally introduced from China into NorthEastern India, from where it has extended into Afghanistan via Punjab, Eastern Afghanistan, together with the adjoining North-Western India is one of the independent centres of origin of brown sarson (Brassica campestris var. brown sarson). India is one of the largest rapeseed mustard growing countries in the world occupying the first position in area and second position in production after China. 
The crop accounts for nearly one third of the oil produced in India, making it the country's second most important edible oil after groundnut (Damodaran and Hegde, 2005). When compared to edible oils, the rapeseed and mustard oil has the lowest amount of harmful saturated fatty acids. It also contains adequate amounts of the two essential fatty acids, linoliec and linolenic, which are not present in many of the other edible oils.

In India it is commercially grown in an area of 5.92 Mha with a production of $6.78 \mathrm{Mt}$ accounting for a productivity of $1145 \mathrm{~kg} / \mathrm{ha}$ (DOAC, 2012). Mustard seed is rich source of energy because of its oil (31-48\%) and protein content (40\%).

Mustard seed contains "erucic acid" which has immense industrial applications. 'High Erucic Acid Rapeseed' (HEAR) oil is the non-edible variety of oil, which is used for industrial purposes. The global market for low erucic acid rapeseed oil is increasing day by day.

Trichoderma, a saprophytic fungus is known to be one of the best candidates of biocontrol agents for the management of soil borne plant pathogens. Mode of action of this fungus include mycoparasitism, antibiosis, competition for nutrient and space, tolerance to stress through enhanced root and plant development, solubilization and sequestration of inorganic nutrients and induced resistance.

The antagonistic action of Trichoderma species against phytopathogenic fungi might be due to either by secretion of extra cellular hydrolytic enzyme (Di Pietro et al., 1993; Schirmbock et al., 1994) or by the production of antibiotics (Dennis and Webster, 1971a, b).

Uses of chemical fungicide are hazardous to human and also to the environment. The regular use of fungicides can potentially pose a risk to the environment, particularly if residues persist in the soil or migrate off-site and enter waterways (e.g. due to spray drift, run-off) (Komarek et al., 2010). If this occurs it could lead to adverse impacts to the health of terrestrial and aquatic ecosystems. For instance, concerns have been raised over the long term use of copper-based fungicides, which can result in an accumulation of copper in the soil (Wightwick et al., 2008; Komarek et al., 2010). This in turn can have adverse effects on soil organisms (e.g. earthworms, microorganisms) and potentially pose a risk to the long-term fertility of the soil (Wightwick et al., 2008). The crop is known to be attacked by number of fungal, bacterial and viral diseases. More than twenty diseases are known to affect the rapeseed mustard group of crops in India, but diseases like White rust and Downy mildew are of major consequences because of their global distribution and heavy yield losses. The disease affects number of Brassica plants of economic importance but its incidence and damage is more in mustard (B.juncea) and rapeseed.

There are several biotic and abiotic factors which hampers the production of Rapeseed and mustard. Among the biotic factors wirestem caused by Rhizoctonia solani is one of the important one. It is a plant pathogenic fungus with a wide host range and worldwide distribution. Rhizoctonia solani frequently exists as thread-like growth on plants or in culture, and is considered a soil-borne pathogen known to cause various plant diseases such as collar rot, root rot, damping off and wire stem. Modern agriculture is slowly changing towards the organic cultivation for sustainability. In view of the important aspects for disease management using biocontrol agents, the present research was undertaken to manage the wire stem of mustard by native Trichoderma spp in Manipur. 


\section{Materials and Methods}

\section{Collection of the disease samples and isolation of pathogen}

Disease plants were collected from the field and samples were cut into small pieces of $1 \mathrm{~mm}$ size. These pieces were surface sterilized with $0.1 \%$ sodium hypochlorite solution for 1 minute and then rinsed with distilled water. The sterilized pieces were then inoculated on PDA slants. The inoculated slants were incubated at $28 \pm 1^{0}$ Cfor 7 days. After 7 days the fungal isolates appearing on the sample pieces were identified and transferred to PDA for purification.

The fungus was identified in the laboratory, Department of Plant Pathology, College of Agriculture, Central Agricultural University, Imphal. Culture was maintained on freshly prepared PDA slants inside the refrigerator and periodically sub cultured to fresh medium during the investigation.

\section{Pathogenicity test}

Pathogenicity test of the isolated fungus was conducted. Soil inoculation with pathogen was done by means of rice seed inoculums technique of Weideman and Wehner (1993).

\section{Biocontrol of Rhizoctonia solaniby native Trichoderma spp.}

In vitro antagonistic potential of some isolates of Trichoderma

The bioagent i.e. four Trichoderma spp (CAUNCIPM-116, CAUNCIPM-97A, CAUNCIPM-11 and CAUNCIPM-50) used in this study were collected from Department of Plant pathology, College of Agriculture, CAU, Imphal. In vitro antagonistic potential of isolates of Trichoderma spp. were evaluated against Rhizoctonia solani Kuhn.
Through dual culture technique, production of non-volatile, volatile antibiotics by Dennis and Webster, 1971a, 1971 b).

\section{Ecological fitness of Trichoderma isolates}

Studies on ecological fitness of Trichoderma spp. was carried out in laboratory and pot experiment using the soil of Manipur. The ecological studies included the competitive parasitic ability and rhizosphere colonization by isolates of Trichoderma.

\section{Determination of microbial population}

The soil samples will be collected from each pot, before sowing the crop, middle of the crop growth and after harvest of the crop for determination of microbial population such as fungi and bacteria (cfu) with the of counter by soil dilution plate technique.

\section{Seed priming with bioagents}

The biopriming of seeds of mustard seed was done by washed seed with distilled water, air dried and finally dipped into the suspension of bioagents for 2-3 mins, stirred thoroughly to ensure uniform coverage of seeds with suspension of bioagents. The treated seeds were spreaded on a cleaned blotter paper and allowed to shade dry. The treated seeds were seeded into petriplates lined with double layered moist blotter paper and covered with upper lid of petriplate lined with moist blotter paper and incubated for one week at $28 \pm 1^{\circ} \mathrm{C}$. Germination of seeds were observed periodically and the root length, shoots length were measured.

The vigour index of respective crop seedlings were calculated on the basis of root and shoot length as follows:

Vigour index of seedlings $=[$ Root length $(\mathrm{cm})$ + shoot length $(\mathrm{cm})] \mathrm{x}$ germination $(\%)$ 
In vivo (pot) efficacy of Trichoderma isolates

Pot experiments to study the efficacy of Trichoderma isolates and chemical treatment against wirestem disease of rapeseed and mustard were taken up at College of Agriculture, Central Agriculture University during kharif season. Pot trails were taken in Completely Randomized design (CRD) with three replications. For pot experiment different treatments were taken up as seed, soil and combination of both along with standard check with seed treatment with Blitox. Observation were recorded on germination percentage, height of the plants, canopy, fresh and dry weight and disease incidence.

Disease incidence of the plants were recorded and calculated by using the formula as given below:

Percent disease incidence $=\frac{\text { Number of diseased plants }}{\text { Total number of plants }} \times 100$

\section{Results and Discussion}

In vitro antagonistic potential of some isolates of Trichoderma

In vitro antagonistic potential of isolates of Trichoderma spp. were evaluated against $R$. solani Kuhn. through dual culture technique.

\section{Effect of volatile antibiotics}

The effect of volatile compounds produced by Trichoderma spp. against Rhizoctonia solani Kuhn. were examined and results are presented in table 1.

Among the four isolates of Trichoderma spp. tested, maximum percentage inhibition was recorded with isolate CAUNCIPM-116 (26.70 per cent) and minimum was recorded with isolate CAUNCIPM-97A (15.50 per cent).

\section{Effect of non-volatile antibiotics}

The effect of non-volatile compounds produced by Trichoderma spp. at two different concentrations against $R$. solani Kuhn. is presented in table 1 . Results showed that per cent inhibition of radial growth of $R$. solani Kuhn. By four isolates of Trichoderma spp. ranged from 7.45 per cent to 31.11 percent at $7.5 \% \mathrm{v} / \mathrm{v}$ concentration and from 14.50 per cent to 33.55 percent at $15 \% \mathrm{v} / \mathrm{v}$.

Competitive parasitic ability of potent Trichoderma spp. against $S$. rolfsii

For the competitive parasitic ability of the four isolates of Trichoderma against $R$. solanion three different soils viz., unsterilized, sun dried and sterilized soil were revealed that the colonization percentage of sclerotia of Rhizoctonia solani by CAUNCIPM116,CAUNCIPM-97A, CAUNCIPM-11 and CAUNCIPM-50 in unsterilized soil were 80.00 percent, 73.33 percent, 66.67 per cent and 73.33 per cent while in sundried soil colonization percentage were $66.67,80.00$, 73.33 and 66.67 percent respectively by the isolates. The degrees of colonization in sterilized soil were 100 percent by the isolates (Table 2).

\section{Microbial population}

The microbial population under pot trails were at 15 and 30 days after planting ranged from were $4.5 \times 10^{8} \mathrm{cfu} / \mathrm{g}$ soil to $6.7 \times 10^{8} \mathrm{cfu} / \mathrm{g}$ soil and $12 \times 10^{8} \mathrm{cfu} / \mathrm{g}$ to $16 \times 10^{8} \mathrm{cfu} / \mathrm{g}$ soil respectively (Fig. 1).

\section{Seed priming with bioagents}

Biopriming of mustard seeds showed that highest root length was observed in isolate CAUNCIPM-97A $(1.70 \mathrm{~cm})$ followed by CAUNCIPM-11 $(1.47 \mathrm{~cm})$, CAUNCIPM-116 $(1.43 \mathrm{~cm})$ and CAUNCIPM-50 $(1.03 \mathrm{~cm})$. However in untreated control the root length 
was only $0.93 \mathrm{~cm}$. The highest shoot length was observed in isolates CAUNCIPM-97A $(5.23 \mathrm{~cm})$ followed by CAUNCIPM-11 (4.90 $\mathrm{cm}), \quad$ CAUNCIPM-116 $(4.70 \mathrm{~cm})$ and CAUNCIPM-50 $(4.40 \mathrm{~cm})$ and in control it was $(4.27 \mathrm{~cm})$. The germination percentage of rapeseed and mustard seeds was found highest in CAUNCIPM-97A with 73.33 per cent followed by CAUNCIPM-11 with 65.45 per cent, CAUNCIPM-116 per cent with 63.15 and CAUNCIPM-50 with 62.00 per cent.

There was only 53.33 per cent seed germination in untreated control. The vigour index was highest in CAUNCIPM-97A (461.98) followed by CAUNCIPM-11 (431.97), CAUNCIPM-116 (397.85), CAUNCIPM-50 (334.80) and lowest (222.80) in untreated control. The biopriming of Rapeseed and mustard seeds were found to be significantly differences among the potent isolates of Trichoderma spp (Table 3, Fig. 2).

\section{Effect of Trichoderma isolates on wire stem of mustard under pot trials}

\section{Germination percentage}

The data on germination percentage were showed that germination percentage in chemical treated seed with Blitox show highest germination percentage with 91.25 per cent followed by seed + soil treated isolate of CAUNCIPM-116 with 88.75 per cent and the least germination percentage was observed in control with 48.75 per cent.

\section{Disease incidence}

The data on disease incidence of wire stem of mustard was showed that in isolate CAUNCIPM-116 seed, soil and combination of seed and soil treatment were 2.93, 2.57 and 1.83 per cent respectively, in isolate CAUNCIPM-97A were $4.95,3.23$ and 3.12 per cent, in isolate CAUNCIPM-11 were $7.13,17.26$ and 7.88 per cent, in isolate CAUNCIPM-50 were 23.21, 8.13 and 20.75 percent respectively and in chemical1.41 per cent, where as in control plot it was 24.80 per cent.

\section{Plant height}

Results on plant height showed that in isolate CAUNCIPM-116 seed, soil and combination of seed and soil treatment, it ranged from 3.98 to $4.80 \mathrm{~cm}, 9.17$ to $11.34 \mathrm{~cm}$ and 14.62 to $14.83 \mathrm{~cm}$ respectively, in CAUNCIPM-97A ranged from 4.61 to $5.44 \mathrm{~cm}, 9.41$ to 12.01 $\mathrm{cm}$ and 14.75 to $17.22 \mathrm{~cm}$, in isolate CAUNCIPM-11 ranged from 4.23 to $5.05 \mathrm{~cm}$ to 10.68 to $11.86 \mathrm{~cm}$ and 13.20 to 15.15 an in isolate CAUNCIPM-50 ranged from 4.60 to $5.21 \mathrm{~cm}, 12.03$ to 12.15 and 13.40 to 17.41 $\mathrm{cm}$ respectively and in chemical ranged from it is $5.95,12.15$ and $17.41 \mathrm{~cm}$ respectively.

Untreated controlled plant height in 10, 20 and 30 days after planting was observed as $3.76,8.73$ and $11.89 \mathrm{~cm}$. respectively.

\section{Plant canopy}

Results showed that in isolates CAUNCIPM116 seed, soil and seed plus soil treatments, it ranged from 5.12 to $10.57 \mathrm{~cm}^{2}, 72.76$ to $107.91 \mathrm{~cm}^{2}$ and 279.07 to $439.73 \mathrm{~cm}^{2}$ respectively, in isolates CAUNCIPM-97A ranged from 7.78 to $10.71 \mathrm{~cm}^{2}, 92.41$ to $159.23 \mathrm{~cm}^{2}$ and 154.10 to $287.65 \mathrm{~cm}^{2}$ respectively, in CAUNCIPM-11 ranged from 3.76 to $10.02 \mathrm{~cm} 2,91.56$ to $142.95 \mathrm{~cm} 2$ and 160.53 to $186.38 \mathrm{~cm} 2$ and in isolate CAUNCIPM-50 ranged from 4.19 to 8.52 $\mathrm{cm} 2,131.27$ to $144.74 \mathrm{~cm} 2$ and 185.59 to $345.17 \mathrm{~cm} 2$ and in chemical it is observed as 12.44, 188.02 and $440.23 \mathrm{~cm}^{2}$ respectively. In control pots, plant canopy is observed as 3.44, 85.83 and $116.17 \mathrm{~cm}^{2}$ respectively. 
Table.1 Effect of volatile and non-volatile compounds of Trichoderma spp. on growth of $R$. solani

\begin{tabular}{|l|l|l|l|l|}
\hline \multirow{2}{*}{ Sl.no. } & \multirow{2}{*}{ Trichodermaspp. } & \multicolumn{3}{|l|}{ Percent inhibition over control } \\
\cline { 3 - 5 } & & Volatile compounds & \multicolumn{2}{l|}{ Non-volatile compounds } \\
\cline { 3 - 5 } & & & $\mathbf{( 7 . 5 \% )}$ & $\mathbf{( 1 5 \% )}$ \\
\hline T1 & CAUNCIPM116 & 26.70 & $11.68(3.48)^{*}$ & $21.49(4.66)$ \\
\hline T2 & CAUNCIPM11 & 25.50 & $31.11(5.62)$ & $33.55(5.83)$ \\
\hline T3 & CAUNCIPM97A & 15.50 & $10.25(3.27)$ & $18.68(4.32)$ \\
\hline T4 & CAUNCIPM50 & 17.50 & $7.45(2.81)$ & $14.50(3.85)$ \\
\hline & S.E(d) \pm & 0.993 & 0.296 & 0.364 \\
\hline & C.D. $(5 \%)$ & 7.990 & 0.314 & 0.793 \\
\hline
\end{tabular}

*Mean of five replications

Values in parentheses are transformed values

Table.2 Competitive parasitic ability of Trichoderma spp. against sclerotia of $R$. solani

\begin{tabular}{|l|l|l|c|}
\hline Type of soil & Treatment & Trichoderma spp. & Percent colonization \\
\hline \multirow{5}{*}{ Un-sterilized } & T1 & CAUNCIPM-116 & $80.00(63.43)^{*}$ \\
\cline { 2 - 4 } & T2 & CAUNCIPM-97A & $73.33(59.21)$ \\
\cline { 2 - 4 } & T3 & CAUNCIPM-11 & $66.67(54.99)$ \\
\cline { 2 - 4 } & T4 & CAUNCIPM-50 & $73.33(59.21)$ \\
\hline \multirow{5}{*}{ Sundried } & T5 & CAUNCIPM-116 & $66.67(54.99)$ \\
\cline { 2 - 4 } & T6 & CAUNCIPM-97A & $80.00(63.43)$ \\
\cline { 2 - 4 } & T7 & CAUNCIPM-11 & $73.33(59.21)$ \\
\cline { 2 - 4 } & T8 & CAUNCIPM-50 & $66.67(54.99)$ \\
\cline { 2 - 4 } & T9 & CAUNCIPM-116 & $100.00(89.54)$ \\
\cline { 2 - 4 } & T10 & CAUNCIPM-97A & $100.00(89.54)$ \\
\cline { 2 - 4 } & T11 & CAUNCIPM-11 & $100.00(89.54)$ \\
\cline { 2 - 4 } & T12 & CAUNCIPM-50 & $100.00(89.54)$ \\
\hline & T13 & CONTROL & $0.00(0.44)$ \\
\hline & \multicolumn{2}{|c}{ CD (d) \pm} & 4.140 \\
\hline
\end{tabular}

*Mean of three replications

Values in parentheses are Square Root Transformed values

Table.3 Biopriming of rapeseed and mustard seed with Trichoderma isolates

\begin{tabular}{|l|l|c|c|c|}
\hline $\begin{array}{c}\text { Sl. } \\
\text { No. }\end{array}$ & Trichoderma spp. & $\begin{array}{c}\text { Root length }(\mathbf{c m}) \\
\text { Mean } \pm \text { SD }\end{array}$ & $\begin{array}{c}\text { Shoot length }(\mathbf{c m}) \\
\text { Mean } \pm \text { SD }\end{array}$ & $\begin{array}{c}\text { Germination } \\
\text { percentage }\end{array}$ \\
\hline 1 & CAUNCIPM116 & $1.43 \pm 0.08$ & $4.70 \pm 0.02$ & 63.15 \\
\hline 2 & CAUNCIPM97A & $1.70 \pm 0.11$ & $5.23 \pm 0.03$ & 73.33 \\
\hline 3 & CAUNCIPM11 & $1.47 \pm 0.02$ & $4.90 \pm 0.02$ & 65.45 \\
\hline 4 & CAUNCIPM50 & $1.03 \pm 0.02$ & $4.40 \pm 0.01$ & 62.00 \\
\hline 5 & Control & $0.93 \pm 0.02$ & $4.27 \pm 0.04$ & 53.33 \\
\hline
\end{tabular}


Table.4 In vivo efficacy Trichoderma spp against wire stem disease of mustard

\begin{tabular}{|c|c|c|c|c|c|c|c|c|c|c|c|c|}
\hline \multirow{2}{*}{$\begin{array}{l}\text { Sl } \\
\text { no. }\end{array}$} & \multirow{2}{*}{$\begin{array}{l}\text { Trichoderma } \\
\text { spp }\end{array}$} & \multirow{2}{*}{ Treatment } & \multirow{2}{*}{$\begin{array}{l}\text { Germination } \\
\text { percentage }\end{array}$} & \multirow{2}{*}{$\begin{array}{c}\text { Disease } \\
\text { incidence } \\
(\%)\end{array}$} & \multicolumn{3}{|c|}{$\begin{array}{c}\text { Plant height }(\mathrm{cm}) \\
\text { (DAS) }\end{array}$} & \multicolumn{3}{|c|}{$\begin{array}{c}\begin{array}{c}\text { Plant canopy }\left(\mathrm{cm}^{2}\right) \\
\text { (DAS) }\end{array} \\
\end{array}$} & \multirow{2}{*}{ 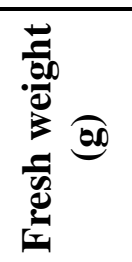 } & \multirow{2}{*}{ 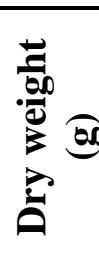 } \\
\hline & & & & & 10 & 20 & 30 & 10 & 20 & 30 & & \\
\hline \multirow{3}{*}{1} & \multirow{3}{*}{$\begin{array}{l}\text { CAUNCIPM } \\
-116\end{array}$} & Seed & $68.33(55.77)$ & $2.93(9.65)$ & 4.80 & 10.27 & 14.83 & 6.20 & 77.30 & 384.71 & 11.07 & 1.94 \\
\hline & & Soil & $86.67(69.55)$ & $2.57(8.75)$ & 3.98 & 9.17 & 14.62 & 10.57 & 72.76 & 279.07 & 10.51 & 2.17 \\
\hline & & $\begin{array}{c}\text { Seed }+ \\
\text { Soil } \\
\end{array}$ & $88.75(70.88)$ & $1.83(7.77)$ & 4.08 & 11.34 & 16.64 & 5.12 & 107.91 & 439.73 & 13.97 & 3.69 \\
\hline \multirow{3}{*}{2} & \multirow{3}{*}{$\begin{array}{c}\text { CAUNCIPM } \\
-97 \mathrm{~A}\end{array}$} & Seed & $76.25(61.44)$ & $4.95(12.75)$ & 4.61 & 9.41 & 14.75 & 8.35 & 92.41 & 195.09 & 15.32 & 4.27 \\
\hline & & Soil & $79.17(62.91)$ & $3.23(10.07)$ & 5.44 & 12.01 & 15.03 & 7.78 & 114.09 & 154.10 & 12.37 & 2.82 \\
\hline & & $\begin{array}{c}\text { Seed + } \\
\text { Soil }\end{array}$ & $85.00(67.29)$ & $3.12(9.98)$ & 4.69 & 11.89 & 17.22 & 10.71 & 159.23 & 287.65 & 12.00 & 3.93 \\
\hline \multirow{3}{*}{3} & \multirow{3}{*}{$\begin{array}{c}\text { CAUNCIPM } \\
-11\end{array}$} & Seed & $55.00(47.89)$ & $7.13(14.73)$ & 5.05 & 11.86 & 13.20 & 10.02 & 128.95 & 160.53 & 15.29 & 2.40 \\
\hline & & Soil & $60.83(51.30)$ & $\begin{array}{c}17.26 \\
(24.29) \\
\end{array}$ & 4.42 & 10.68 & 15.15 & 3.76 & 91.56 & 233.19 & 10.98 & 1.76 \\
\hline & & $\begin{array}{l}\text { Seed }+ \\
\text { Soil }\end{array}$ & $80.83(64.08)$ & $7.88(15.57)$ & 4.23 & 11.37 & 13.42 & 7.22 & 142.95 & 186.38 & 13.97 & 2.96 \\
\hline \multirow{3}{*}{4} & \multirow{3}{*}{$\begin{array}{c}\text { CAUNCIPM } \\
-50\end{array}$} & Seed & $77.92(62.05)$ & $\begin{array}{c}23.21 \\
(28.78) \\
\end{array}$ & 4.60 & 10.21 & 12.35 & 7.56 & 144.74 & 185.59 & 15.40 & 4.57 \\
\hline & & Soil & $85.83(68.21)$ & $8.13(16.34)$ & 5.05 & 11.22 & 13.15 & 8.52 & 131.27 & 313.97 & 11.94 & 1.84 \\
\hline & & $\begin{array}{c}\text { Seed }+ \\
\text { Soil } \\
\end{array}$ & $70.83(57.42)$ & $\begin{array}{l}20.75 \\
(27.04) \\
\end{array}$ & 5.21 & 12.03 & 13.40 & 4.19 & 136.76 & 345.17 & 17.14 & 3.33 \\
\hline 5 & \multicolumn{2}{|c|}{ Blitox } & $91.25(73.06)$ & $1.41(6.82)$ & 5.95 & 12.15 & 17.41 & 12.44 & 188.02 & 440.23 & 18.04 & 4.57 \\
\hline 6 & \multicolumn{2}{|c|}{ Control } & $48.75(44.28)$ & $\begin{array}{c}24.80 \\
(29.85) \\
\end{array}$ & 3.79 & 8.73 & 11.89 & 3.44 & 85.83 & 116.17 & 7.45 & 1.70 \\
\hline \multicolumn{3}{|c|}{ S.E (d) \pm} & 4.06 & 2.64 & 0.345 & 1.107 & 1.035 & 1.265 & 21.164 & 43.913 & 1.54 & 0.56 \\
\hline \multicolumn{3}{|c|}{ C.D. $(5 \%)$} & 8.35 & 5.43 & 0.709 & 2.275 & 2.127 & 2.601 & 43.503 & 90.264 & 3.17 & 1.15 \\
\hline
\end{tabular}


Fig.1 Fungal microbial population from the rhizosphere of mustard plant at 15 and 30 days after planting

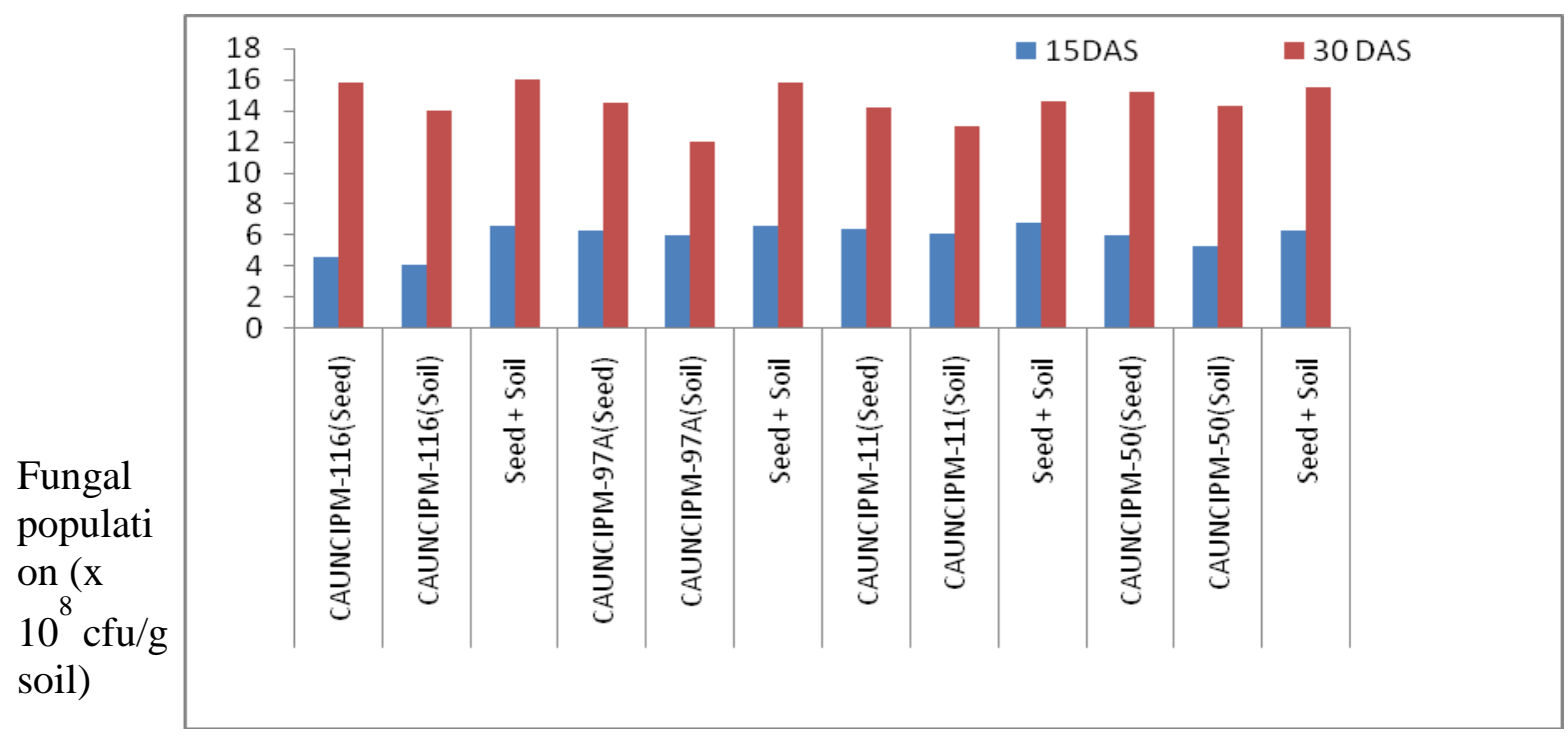

Fig.2 Vigour index of mustard seed by treatment of Trichoderma spp.

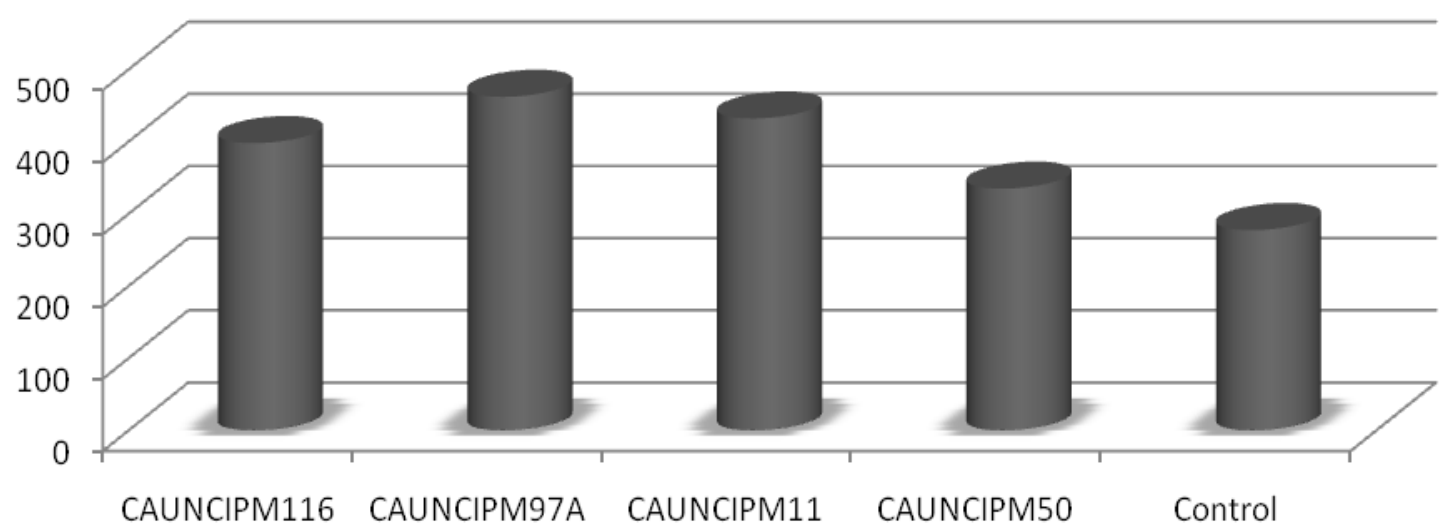

\section{Fresh weight}

The data on fresh weight of rapeseed and mustard plants was recorded at the time of harvest and result presented in table 4 . Results showed that in isolates CAUNCIPM-116 seed, soil and seed plus soil treatments, it ranged from 10.51 to $13.97 \mathrm{~g}$, in isolate CAUNCIPM97A ranged from 12.00 to $15.32 \mathrm{~g}$, in isolate CAUNCIPM-11 ranged from 10.98 to $15.29 \mathrm{~g}$, in isolate CAUNCIPM-50 ranged from 11.94 to
$17.14 \mathrm{~g}$, and Chemical treated pot the fresh weight showed highest fresh weight with 18.04 g. Lowest fresh weight of rapeseed and mustard was observed in control pot with $7.45 \mathrm{~g}$.

\section{Dry weight}

The data on dry weight of rapeseed and mustard plants was recorded at the time of harvest and result presented in table 4 . Results showed that in isolates CAUNCIPM-116 seed, soil and seed 
plus soil treatments, it ranged from 1.94 to $3.69 \mathrm{~g}$, in isolate CAUNCIPM-97A ranged from 2.82 to $4.27 \mathrm{~g}$, in isolate CAUNCIPM-11 ranged from 1.70 to $2.96 \mathrm{~g}$, in isolate CAUNCIPM-50 ranged from 1.84 to $4.57 \mathrm{~g}$, and Chemical treated pot the fresh weight showed highest fresh weight with $4.57 \mathrm{~g}$. Lowest fresh weight of rapeseed and mustard was observed in control pot with $1.70 \mathrm{~g}$.

It is important to mention that Trichoderma spp. are known to produce a number of antibiotics such as Trichodermin, Trichodermol, Harzianum A, Hrazianolide (Dennis and Webster, 1971a,b; Kucuk and Kivanc, 2004) as well as some cell wall degrading enzymes such as chitinases, glucanases that break down polysaccharides, chitins and beta glucanase destroying cell wall (Elad, 2000).

Yan et al., 2006 revealed that antimicrobial metabolites produced by Trichoderma is effective against a wide range of fungal pathogens eg. Fusarium, Rhizoctonia, Curvularia, Bipolaris and Colletotrichum.

Present findings suggested that the test isolates of Trichoderma varied in their ability to colonize the sclerotia of $R$. solani and $S$. rolfsii. These findings are in accordance with Hennis et al., (1983) who have shown that strains of Trichoderma spp. varied in their ability to colonize the sclerotia of $S$. rolfsii. The possible role of lectin in specific recognition between Trichoderma spp. and S. rolfsii and colonization of sclerotia has been highlighted (Barak et al., 1985).

The inoculation of seeds with biological agents in combination with priming has been reported to enhance and stabilize the efficacy of biological agents (Moeinzadeh et al., 2010; Bennett and Whipps, 2008).

In vivo efficacy of four isolates viz., CAUNCIPM-116, CAUNCIPM-97A, CAUNCIPM-11 and CAUNCIPM-50 of Trichoderma against Rhizoctonia solani Kuhn.showed significant reduction in disease incidences under pot condition and combination of seed and soil treatment with Trichoderma isolates showed highest plant height, plant canopy, fresh weight, dry weight and yield.

Likewise there are several reports of biocontrol of pathogens in vivo and under field conditions against soil borne diseases (Mishra et al., 2011). Similarly, Prasad et al., (2002) reported that biopriming with Trichoderma resulted into increased germination (\%) root and shoot length of red gram under field condition. Increased plant fresh weight (140\%) and foliar area $(300 \%)$, as well as proliferation of secondary roots $(300 \%)$ and true leaves $(140 \%)$. McLean et al., (2005) observed that onion roots became free from Sclerotium cepivorum by application of $T$. atroviride under both green house and field condition. Present findings are in consistent with the earlier findings (Joshi et al., 2010). Lo et al., (2002) reported that the Trichoderma treated plant promote root growth of bitter gourd, loofah and cucumber. The experiment in greenhouse showed that the plant treated with Trichoderma spp significantly increased seedling height (26 to $61 \%$ ), root exploration (85 to $209 \%$ ) leaf area (27 to $38 \%$ ) and root dry weight (38 to $62 \%$ ) after 15 DAS of bitter gourd. Similarly these Trichoderma strains also increased the seedling growth of loofah and cucumber.

\section{References}

Barak, R., Elad, Y., Mirelman, D. and Chet, I. 1985. A possible basis for specific recognition in the interaction of Trichoderma and Sclerotium rolfsii. Phytopathology, 75: 458-62.

Dennis, C., and Webster, J. 1971a. Antagonists' properties of species groups of Trichoderma 1. Production of nonvolatile antibiotics. T. Brit. Mycol. Soc., 57: 25-39.

Dennis, C., and Webster, J. 1971b. Antagonistic properties of species groups of Trichoderma 11. Production of volatile antibiotics. T. Brit. Mycol. Soc., 57: 4148. 
Di Pietro, A., Lorito, M., Hayes, C., Broadway, K. and Harman, G.E. 1993. Endochitinase from Gliocladium virens. Isolation, characterization, synergistic antifungal activity in combination with gliotoxin. Phytopathology, 83: 308-313.

DOAC. 2012. Agricultural Statistics at a glance. Dir. Econ. And Stat., Dep. Agric. and Corp., Ministry of Agriculture, Government of India

Elad, Y., 2000. Biological control of foliar pathogens by means of Trichoderma harzianum and potential modes of action. Crop. Prot., 19: 709-714.

Hennis, Y., Adams, P.B., Lewis, J.A. and Papavizas, G.C. 1983. Penetration of sclerotia of Sclerotium rolfsii by Trichoderma spp. Phytopathology, 73: 1043-46.

Joshi, B.B., Bhatt, R.P. and Bahukhandi, D. 2010. Antagonistic and plant growth activity of Trichoderma isolates of Western Himalayas. J. Environ. Bio, 31(6): 921-928.

Komarek, M., Cadkova, E., Chrastny, V., Bordas, F. and Bollinger, J-C. 2010. Contamination of vineyard soils with fungicides: A review of environmental and toxicological aspects. Environ. Int., 36: $138-151$

Kucuk, C., and Kivanc, M. 2004. In vitro antifungal activity of strains of Trichoderma harzianum. Turk. J. Biol, 28: 111-115.

Lo, C.T., and Lin, C.Y. 2002. Screening strain of Trichoderma spp. for growth enhancement in Taiwan. Plant Pathol. Bull., 11: 215-220.
McLean, K.L., Swaminathan, J., Frampton, C.M., Hunt, J.S., Ridgway, H.J and Stewart, A. 2005. Effect of formulation on the rhizosphere competence and biocontrol ability of Trichoderma atroviride C52. Plant Pathol, 54: 212218.

Mishra, B.K., Mishra, R.K., Mishra, R.C., Tiwari, A.K., Yadav, R.S. and Dikshit, A. 2011. Biocontrol efficacy of isolates Trichoderma viride against fungal plant pathogens causing disease in Vigna radiate L. Arch. Appl. Sci. Res.,3(2): 361369.

Prasad, R.D., Rangeshwaran, R., Anuroop, C.P. and Rashni, H.J. 2002. Biological control of wilt and root rot of chickpea under field conditions. Ann. Pl. Prot. Sci., 10 (1): 72-75.

Schirmbock, M., Lorito, M., Wang, Y.L., Hayes, C.K., Arisan-Atac, I., Scala, F., Harman, G.E. and Kubicek, C.P. 1994. Parallel formation and synergism of hydrolytic enzymes and peptaibol antibiotics, molecular mechanisms involved in the antagonistic action of Trichoderma harzianum against phytopathogenic fungi. Appl. Environ. Microbiol. 60: 4364-4370.

Wightwick, A., Mollah, M., Partington, D. \& Allinson, G. 2008. Copper fungicide residues in Australian vineyard soils. $J$. Agr. Food Chem., 56: 2457-2464.

Yan, S.P., Zhang, Q.Y., Tang, Z.C., Su, W.A. and Sun, W.N. 2006. Comparative proteomic analysis provides new insights into chilling stress responses in rice. Mol. Cell. Proteomics, 5: 484-496.

\section{How to cite this article:}

Nirupama Devi, R.K., Bireswar Sinha and Sobita Devi Ph. 2017. Native Trichoderma for the Management of Wire Stem of Mustard (Brassica spp) Caused by Rhizoctonia solani. Int.J.Curr.Microbiol.App.Sci. 6(9): 2319-2328. doi: https://doi.org/10.20546/ijcmas.2017.609.284 